\title{
Ekstrak Daun Mengkudu dan Daun Pepaya Sebagai Larvasida Alami terhadap Kematian Larva Nyamuk Aedes Aegypti
}

\author{
Veronika Amelia Simbolon ${ }^{1}$, Indra Martias ${ }^{2}$ \\ ${ }^{1,2}$ Poltekkes Kemenkes Tanjungpinang \\ Jl. Arif Rahman Hakim, Sei Jang, Kota Tanjung Pinang, Kepulauan Riau \\ Email: ${ }^{1}$ veronikaameliasimbolon@gmail.com, ${ }^{2}$ indramartias25@gmail.com
}

\begin{abstract}
Abstrak
Penggunaan larvasida kimiawi yang digunakan untuk mengontrol aedes aegypti telah menimbulkan populasi yang resistensi, sehingga dibutuhkan dosis yang lebih tinggi. Namun hal ini memiliki efek toksik bagi manusia, hewan, serta lingkungan. Larvasida alami merupakan larvasida yang dibuat dari tanaman yang mempunyai kandungan beracun terhadap serangga pada stadium larva dan tidak menimbulkan efek samping terhadap lingkungan. Penelitian ini bertujuan untuk mengetahui kemampuan dari ekstrak daun mengkudu, daun papaya dan kombinasi keduanya dalam mengendalikan larva Aedes aegypti. Jenis penelitian yang digunakan dalam penelitian ini adalah eksperimental laboratorium dengan desain Rancangan Acak Kelompok (RAK). Objek penelitian adalah larva Aedes aegypti sebanyak 400 larva. Uji dibagi menjadi 4 kelompok dengan dua kali pengulangan. Analisis yang digunakan adalah analisis univariat dan bivariat. Hasil penelitian menunjukkan terdapat perbedaan jumlah kematian larva pada pengulangan I dan II sedangkan rata-rata $\mathrm{PH}$ air, suhu air dan kelembaban udara tidak menunjukkan perbedaan yang signifikan. Disimpulkan bahwa kombinasi ekstrak daun mengkudu dan daun pepaya lebih efektif sebagai larvasida alami untuk kematian larva Aedes. Disarankan melakukan analisis probit untuk mendapatkan nilai toksisitas (daya racun) terhadap serangga percobaan dan pengujian terhadap insektisida kimiawi sebagai pembanding (kontrol) terhadap insektisida alami.
\end{abstract}

Kata Kunci : Aedes aegypti, larvasida, daun mengkudu, daun pepaya

\begin{abstract}
The use of chemical larvicides used to control aedes aegypti has given rise to resistant populations, so higher doses are needed. But this has toxic effects on humans, animals and the environment. Natural larvicides are larvicides that are made from plants that have poisonous contents against insects at the larval stage and do not cause side effects on the environment. This study aims to determine the ability of noni leaf extract, papaya leaf and a combination of both in controlling Aedes aegypti larvae. This type of research used in this study is an experimental laboratory design with Random Group Design (RBD). The object of research is 400 larvae of Aedes aegypti. The test was divided into 4 groups with two repetitions. The analysis used is univariate and bivariate analysis. The results showed that there were differences in the number of larval deaths in I and II repetitions while the average water $\mathrm{PH}$, water temperature and humidity did not show a significant difference. It was concluded that the combination of noni leaf extract and papaya leaf was more effective as a natural larvicide for the death of Aedes larvae. It is recommended to conduct probit analysis to get the value of toxicity (poison power) on experimental insects and testing of chemical insecticides as a comparison (control) of natural insecticides.
\end{abstract}

Keywords: Aedes aegypti, larvicide, noni leaf, papaya leaf 


\section{Pendahuluan}

Pada tahun 2013 dilaporkan terdapat sebanyak 2,35 juta kasus DBD di Amerika, dimana 37.687 kasus merupakan DBD berat. Perkembangan kasus DBD di tingkat global semakin meningkat, seperti dilaporkan Organisasi Kesehatan Dunia (WHO) yakni dari 980 kasus di hampir 100 negara tahun 1954-1959 menjadi 1.016.612 kasus di hampir 60 negara tahun 2000-2012. ${ }^{1}$

Berdasarkan data dan informasi profil kesehatan Indonesia tahun 2017 diketahui jumlah kasus DBD di Indonesia sebanyak 59.047 kasus, dengan jumlah yang meninggal adalah 444 orang, incidence rate 22,55 per 100.000 penduduk dan case fatality rate $0,75 \%$. Daerah Kepulauan Riau diketahui jumlah kasus DBD sebanyak 632 kasus, jumlah yang meninggal 11 orang, incidence rate 30,35 per 100.000 penduduk dan case fatality rate $1,74 \% .^{2}$ Kejadian demam berdarah di Kota Tanjungpinang penyumbang terbanyak kejadian DBD adalah Kecamatan Tanjungpinang Timur. Berdasarkan data 5 tahun terakhir pada tahun 2013 terdapat 66 kasus, 317 kasus tahun 2014, tahun 2015 ada 216 kasus. Laporan tahun 2016 menunjukan 120 kasus dan tahun 2017 sebanyak 37 kasus. ${ }^{3}$ Selama 5 tahun terakhir kematian akibat DBD selalu terjadi Kecamatan Tanjung Pinang Timur dengan kejadian terakhir pada awal tahun 2019 ini. $^{4}$

Penggunaan larvasida kimiawi konvensional yang digunakan untuk mengontrol Aedes aegypti telah menimbulkan populasi yang resistensi sehingga dibutuhkan dosis yang lebih tinggi yang tentu memiliki efek toksik bagi manusia, hewan, serta lingkungan. Uji coba yang dilakukan di Martinique (French West Indies) menunjukkan telah terjadi resistensi terhadap insektisida Pyrethroid sehingga terjadi penurunan efikasi. Themepos organofosfat adalah larvasida yang digunakan secara luas sebagai pengendalian vektor dengue di Martinique yang telah menunjukkan resistensi di Asia Tenggara, Amerika Selatan, dan Karibia. ${ }^{5}$

Menurut Basimeye, jus daun mengkudu mengandung tanin sebanyak $5,12 \%$ saponin sebanyak $0,18 \%$, dan flavonoid sebanyak 43,9\%, dimana senyawa-senyawa tersebut dapat membunuh larva Aedes aegypti. Ekstrak daun pepaya (Carica papaya Linn) memiliki sifat sebagai larvasida, ovisida dan repellan, karena di dalam daun pepaya memiliki berbagai zat metabolit aktif yang diduga berguna sebagai larvasida. Zat metabolit aktif yang terkandung berupa alkaloid, tanin, phenolics, saponin, flavonoid dan steroid. ${ }^{6}$

Berdasarkan kesamaan kandungan dari kedua flora ini yaitu mengandung flavonoid, tannin, dan saponin yang memiliki kemampuan sebagai larvasida alami terhadap kematian jentik Aedes aegypti, maka peneliti merasa perlu melakukan penelitian mengenai ekstrak daun mengkudu dan ekstrak daun papaya sebagai insektisida alami yang dapat berfungsi sebagai alternatif untuk mengendalikan populasi Aedes aegypti yang telah resisten terhadap penggunaan insektisida berbahan kimia.

\section{Metode Penelitian}

Jenis penelitian yang digunakan dalam penelitian ini adalah eksperimental laboratorium dengan desain Rancangan Acak Kelompok (RAK), dimana dalam rancangan ini, percobaan dipetakan dan dibagi menjadi beberapa kelompok. ${ }^{7}$ Objek penelitian dalam penelitian ini adalah larva Aedes aegypti. Jentik nyamuk diperoleh dari pengambilan jentik oleh juru pemantau jentik yang ada di kecamatan Tanjungpinang Timur. Besar pengulangan pada penelitian ini dapat dihitung dengan menggunakan rumus Federer. Berdasarkan hasil perhitungan yang dilakukan maka besar pengulangan per kelompok minimal 2 kali pengulangan. Total sampel yang digunakan yaitu 400 larva Aedes aegypti. ${ }^{8}$

Penelitian ini menggunakan analisis univariat untuk menjelaskan atau mendeskripsikan distribusi frekuensi dari masing-masing variabel yaitu kondisi tempat hidup larva ( $\mathrm{pH}$ air, suhu air dan kelembaban), jumlah kematian larva dengan 
Tabel 1. Jumlah sampel yang digunakan dalam penelitian (WHOPES, 2009)

\begin{tabular}{|c|c|c|c|c|c|c|c|c|c|}
\hline \multirow[t]{2}{*}{ Jenis Ekstrak } & \multicolumn{4}{|c|}{$\begin{array}{c}\text { Waktu Pengamatan dan } \\
\text { Pengulangan I }\end{array}$} & \multicolumn{4}{|c|}{$\begin{array}{c}\text { Waktu Pengamatan dan } \\
\text { Pengulangan II }\end{array}$} & \multirow[t]{2}{*}{ Total } \\
\hline & 1 & 6 & 12 & 24 & 1 & 6 & 12 & 24 & \\
\hline Pepaya (P) & \multicolumn{4}{|c|}{50 larva } & \multicolumn{4}{|c|}{50 larva } & 100 larva \\
\hline Mengkudu (M) & \multirow{2}{*}{\multicolumn{4}{|c|}{$\begin{array}{l}50 \text { larva } \\
50 \text { larva }\end{array}$}} & \multicolumn{4}{|c|}{50 larva } & 100 larva \\
\hline Kombinasi (K) & & & & & \multicolumn{4}{|c|}{50 larva } & 100 larva \\
\hline Kontrol (C) & \multicolumn{4}{|c|}{50 larva } & \multicolumn{4}{|c|}{50 larva } & 100 larva \\
\hline Jumlah & \multicolumn{4}{|c|}{200 larva } & \multicolumn{4}{|c|}{200 larva } & 400 larva \\
\hline
\end{tabular}

ekstrak daun papaya, dan jumlah kematian larva dengan ekstrak daun mengkudu. Analisis bivariat menggunakan uji one way anova apakah data terdistribusi normal dan varians data sama. Apabila tidak memenuhi syarat keduanya maka menggunakan uji saphiro Wilk . Apabila hasil uji one way anova maupun uji saphiro Wilk menunjukkan nilai $\mathrm{pv}<0,05$, maka dilanjutkan dengan analisis post hoc. ${ }^{9}$

\section{Hasil}

Penelitian ini menggunakan larva nyamuk Aedes 400 ekor dan dilihat banyaknya larva yang mati pada pengulangan ke-I dan pengulangan ke-II. Ekstrak daun papaya dan daun mengkudu diencerkan sampai didapatkan konsentrasi $2 \%$ untuk daun papaya dan $0,5 \%$ untuk daun mengkudu.

Tabel 2. Jumlah kematian larva nyamuk Aedes pada Pengulangan ke-I dan II dengan Ekstrak Daun Mengkudu konsentrasi 2\%

\begin{tabular}{lccccccccc}
\hline $\begin{array}{c}\text { Waktu } \\
\text { Pengamatan }\end{array}$ & \multicolumn{2}{c}{$\begin{array}{c}\text { Jumlah } \\
\text { Kematian } \\
\text { Larva (ekor) }\end{array}$} & PH & & Suhu $\left({ }^{\mathbf{0}} \mathbf{C}\right)$ & \multicolumn{2}{c}{$\begin{array}{c}\text { Kelembaban } \\
(\%)\end{array}$} \\
\hline Pengulangan & I & II & I & II & I & II & I & II \\
\hline Jam ke - 1 & 4 & 2 & 5,2 & 5,8 & 28 & 28,5 & 63 & 60 \\
Jam ke - 6 & 10 & 6 & 4,8 & 5,1 & 28 & 29 & 60 & 60 \\
Jam ke - 12 & 5 & 8 & 4,8 & 5,3 & 29 & 29 & 60 & 60 \\
Jam ke - 24 & 8 & 9 & 4,5 & 5 & 28,5 & 28 & 59 & 59 \\
\hline Jumlah & 27 & 25 & & & & & & \\
\hline Rata-rata & 7 & 6 & 4,83 & 5,3 & 28,38 & 28,62 & 60,5 & 59,75 \\
\hline
\end{tabular}

Berdasarkan tabel 2 terlihat adanya perbedaan jumlah total kematian larva pada pengulangan I dan II. Pada pengulangan I jumlah kematian terbanyak pada pengamatan jam ke-6 sebanyak 10 ekor sedangan pengulangan II pada jam ke-24 sebanyak 9 ekor. Hasil pengukuran pada pengulangan I dan II menunjukan rata-rata PH air, suhu air dan kelembaban udara tidak menunjukkan perbedaan yang signifikan.

Berdasarkan Tabel 3 dapat dikatakan bahwa adanya perbedaan jumlah total kematian larva pada pengulangan I dan II. Pada pengulangan I jumlah kematian terbanyak pada pengamatan jam ke-12 dan ke-24 sebanyak 10 ekor sedangan pengulangan II pada jam ke-6 sebanyak 10 ekor. Hasil pengukuran pada pengulangan I dan II menunjukan rata-rata $\mathrm{PH}$ air, suhu air dan kelembaban udara tidak menunjukkan perbedaan yang signifikan.

Berdasarkan Tabel 4 terlihat adanya perbedaan jumlah total kematian larva pada pengulangan I dan II. Pada pengulangan I jumlah kematian terbanyak pada pengamatan jam ke-6 sebanyak 20 ekor sedangan pengulangan II juga pada jam ke-6 sebanyak 18 ekor. Hasil pengukuran pada pengulangan I dan II menunjukan rata-rata PH air, suhu air dan kelembaban udara tidak menunjukkan perbedaan yang signifikan. 
Berdasarkan tabel 5, data variabel berdistribusi normal dimana batas penerimaan normalitas untuk uji Shapiro-Wilk sebesar p 0,05 dan kurva normal histogram dalam keadaan simetris, sehingga analisis bivariat menggunakan uji One Way Anova dapat dilakukan.
Berdasarkan tabel 6 diperoleh nilai Pvalue sebesar $0,015<0,05$, dengan demikian ada efektifitas ekstrak daun mengkudu, daun papaya dan kombinasi sebagai larvasida alami terhadap kematian larva nyamuk Aedes.

Tabel 3. Jumlah kematian larva nyamuk Aedes pada Pengulangan ke-I dan II dengan Ekstrak Daun Pepaya konsentrasi 0,5\%

\begin{tabular}{lcccccccc}
\hline $\begin{array}{c}\text { Waktu } \\
\text { Pengamatan }\end{array}$ & $\begin{array}{c}\text { Jumlah } \\
\text { Kematian } \\
\text { Larva (ekor) }\end{array}$ & PH & & Suhu $\left({ }^{\mathbf{0}} \mathbf{C}\right)$ & \multicolumn{2}{c}{$\begin{array}{c}\text { Kelembaban } \\
(\%)\end{array}$} \\
\hline Pengulangan & I & II & I & II & I & II & I & II \\
\hline Jam ke -1 & 3 & 2 & 6,4 & 6,4 & 28 & 28 & 59 & 58 \\
Jam ke - 6 & 7 & 10 & 6,2 & 6,3 & 31 & 28 & 55 & 59 \\
Jam ke -12 & 10 & 7 & 5,8 & 6,5 & 30 & 29 & 53 & 58 \\
Jam ke - 24 & 10 & 8 & 5.3 & 6,5 & 31 & 29,5 & 53 & 60 \\
\hline Jumlah & 29 & 27 & & & & & & \\
\hline Rata-rata & 7 & 7 & 5,93 & 6,42 & 30 & 28,63 & 55 & 58,75 \\
\hline
\end{tabular}

Tabel 4. Jumlah kematian larva nyamuk Aedes pada Pengulangan ke-I dan II dengan Ekstrak Kombinasi Daun Mengkudu 2\% dan Daun Pepaya 0,5\%

\begin{tabular}{lcccccccc}
\hline $\begin{array}{c}\text { Waktu } \\
\text { Pengamatan }\end{array}$ & $\begin{array}{c}\text { Jumlah } \\
\text { Kematian } \\
\text { Larva (ekor) }\end{array}$ & PH & & Suhu ( & & \multicolumn{2}{c}{$\begin{array}{c}\text { Kelembaban } \\
(\%)\end{array}$} \\
\hline Pengulangan & I & II & I & II & I & II & I & II \\
\hline Jam ke - 1 & 6 & 6 & 4,8 & 5 & 29 & 27 & 59 & 60 \\
Jam ke - 6 & 20 & 18 & 4,5 & 5,2 & 29 & 28 & 57 & 59 \\
Jam ke - 12 & 12 & 17 & 4,7 & 5,3 & 30 & 27 & 58 & 58 \\
Jam ke - 24 & 14 & 8 & 4,6 & 5,2 & 29 & 27 & 59 & 58 \\
\hline Jumlah & 50 & 49 & & & & & & \\
\hline Rata-rata & 12 & 12 & 4,65 & 5,18 & 29,25 & 27,25 & 58,25 & 58,75 \\
\hline
\end{tabular}

Tabel 5. Hasil Uji Normalitas Data

\begin{tabular}{lccc}
\hline \multicolumn{1}{c}{ Variabel } & Shapiro-Wilk & Kurva Normal Histogram & Normalitas \\
\hline Ekstrak Mengkudu 2\% & 0,797 & Simetris & Normal \\
Ekstrak Pepaya 0,5\% & 0,088 & Simetris & Normal \\
Kombinasi Mengkudu 2\% dan Pepaya 0,5\% & 0,290 & Simetris & Normal \\
\hline
\end{tabular}

Tabel 6. Hasil Uji One Way Anova

\begin{tabular}{lcccc}
\hline \multicolumn{1}{c}{ Variabel } & N & Mean & Std Deviation & P value \\
\hline Ekstrak Mengkudu 2\% & 8 & 6,56 & 2,726 & \\
Ektrak Pepaya 0,5 \% & 8 & 7,25 & 3,137 & 0,015 \\
Kombinasi & 8 & 12,31 & 5,605 & \\
\hline
\end{tabular}


Tabel 7. Signifikansi Konsentrasi

\begin{tabular}{llc}
\hline $\begin{array}{c}\text { Variasi Konsentrasi } \\
\text { Ekstrak (I) }\end{array}$ & \multicolumn{1}{c}{$\begin{array}{c}\text { Variasi Konsentrasi } \\
\text { Ekstrak (J) }\end{array}$} & P value \\
\hline Mengkudu & Pepaya & 0,677 \\
& Kombinasi & 0,018 \\
Pepaya & Mengkudu & 0,677 \\
& Kombinasi & 0,037 \\
Kombinasi & Mengkudu & 0,018 \\
& Pepaya & 0,037 \\
\hline
\end{tabular}

Berdasarkan tabel 7, nilai Pvalue akhir antara konsentrasi ekstrak mengkudu dengan papaya adalah $>0,05$ sedangkan ekstrak pepaya dengan kombinasi dan ekstrak mengkudu dengan kombinasi adalah $<0,05$ sehingga dapat disimpulkan ekstrak mengkudu dengan kombinasi dan ekstrak papaya dengan kombinasi lebih efektif sebagai larvasida alami untuk kematian larva Aedes.

\section{Pembahasan}

Pada saat penelitian berlangsung suhu ekstrak berkisar $28^{\circ} \mathrm{C}-31^{\circ} \mathrm{C}$. Hal ini menunjukkan bahwa suhu tersebut tidak terlalu tinggi, sehingga proses penguraian berjalan lambat. Suhu larutan merupakan faktor pengaruh dalam pertumbuhan dan perkembangan larva nyamuk Aedes aegypti. Suhu larutan yang sesuai untuk perkembangan larva nyamuk Aedes aegypti antara $25^{\circ} \mathrm{C}-30^{\circ} \mathrm{C} .^{9}$ Pada suhu tersebut larva nyamuk Aedes aegypti akan berkembang secara optimal. Hal ini berarti suhu larutan yang digunakan dalam penelitian ini berada dalam suhu normal untuk berkembangnya larva nyamuk Aedes aegypti. Sehingga suhu tidak memberikan pengaruh terhadap kematian larva Aedes aegypti pada penelitian ini. ${ }^{10}$ Kelembaban yang diukur berkisar antara 53\% - 63\%. Syarat untuk berkembang biak larva Aedes aegypti yaitu berada pada kelembaban yang kondusif adalah antara 60\%-80\%, sedangkan tingkat kelembaban $60 \%$ merupakan batas yang paling rendah untuk memungkinkan hidupnya nyamuk. ${ }^{10}$

Berdasarkan hasil penelitian pada pengulangan I dan pengulangan II, penggunaan larvasida alami dari ekstrak daun mengkudu dapat diketahui bahwa semakin lama waktu kontak larva dengan larvasida alami semakin tinggi jumlah kematian larva Aedes. Pada pengulangan I jumlah kematian larva sebanyak 27 ekor dan pada pengulangan II jumlah kematian larva sebanyak 25 ekor. Hal ini sesuai dengan penelitian yang dilakukan oleh Nisa dkk, bahwa ekstrak biji dan daun mengkudu dengan konsentrasi 2\% memiliki daya bunuh yang cukup kuat terhadap larva Aedes. ${ }^{11}$ Ekstrak biji mengkudu pada konsentrasi $2 \%$ dapat mematikan 20 ekor larva Aedes dan ekstrak daun mengkudu pada konsentrasi yang sama mampu mematikan 9 ekor larva Aedes.

Pada penelitian ini kematian larva Aedes ditandai dengan melemahnya larva saat disentuh atau digerakkan dan perlahan larva mati. Hal ini dipengaruhi oleh kombinasi dari saponin dan tanin sebagai racun perut dan flavonoid sebagai racun pernapasan memiliki daya bunuh terhadap kematian larva Aedes aegypti. Larva Aedes aegypti yang telah diberikan konsentrasi air perasan daun mengkudu akan mengalami perubahan tingkah laku dimana gerakan yang sebelumnya aktif akan menjadi lamban, dan akhirnya akan mati. ${ }^{12}$

Hasil perlakuan dan pengamatan yang telah dilakukan, diketahui bahwa ekstrak kombinasi daun mengkudu $2 \%$ dan pepaya $0,5 \%$ memberikan pengaruh terhadap kematian larva Aedes. Pada pengulangan I larva Aedes mati berjumlah 50 ekor dan pada pengulangan II jumlah kematian larva adalah 49 ekor. Kematian larva pada perlakuan ini mengalami peningkatan jumlah dari perlakukan konsentrasi ekstrak sebelumnya.

Kombinasi dari berbagai senyawa aktif yang terdapat dalam ekstrak daun 
mengkudu dan daun pepaya yakni papain, alkoloid, saponin, tanin, dan flavonoid memiliki efek larvasida. Kombinasi dari saponin dan tanin sebagai racun perut dan flavonoid sebagai racun pernapasan berpengaruh terhadap kematian larva Aedes sp 12. ${ }^{13}$ Larva Aedes sp yang telah diberikan ekstrak daun mengkudu dan ekstrak daun pepaya akan mengalami perubahan tingkah laku dimana gerakan yang sebelumnya aktif akan menjadi lamban, dan akhirnya akan mati. Larva Aedes sp dikatakan mati apabila larva tersebut sudah tidak bergerak bila disentuh dan berada di dasar air, serta tidak muncul lagi ke permukaan air. Larva yang mati nampak kelihatan putih pucat. ${ }^{14}$

Berdasarkan uji Bofferroni yang telah dilakukan diketahui $P$ value nilai akhir antara konsentrasi ekstrak mengkudu dengan papaya adalah > 0,05 sedangkan ekstrak pepaya dengan kombinasi dan ekstrak mengkudu dengan kombinasi adalah $<0,05$ sehingga dapat disimpulkan ekstrak mengkudu dengan kombinasi dan ekstrak papaya dengan kombinasi lebih efektif sebagai larvasida alami untuk kematian larva Aedes. Kombinasi ekstrak daun mengkudu dan daun pepaya memilki berbagai senyawa aktif antara lain papain, alkoloid, saponin, tanin dan flavonoid yang memiliki efek larvasida dan didukung dengan konsentrasi kombinasi ekstrak yang semakin besar dan mengakibatkan semakin banyak kandungan senyawa aktif. Sehingga semakin banyak pula racun yang dikonsumsi larva Aedes.

\section{Kesimpulan}

Terdapat perbedaan jumlah kematian larva Aedes pada pengulangan I dan II dengan menggunakan ekstrak daun mengkudu konsentrasi $2 \%$ dan ekstrak daun papaya konsentrasi $0,5 \%$. Pengukuran rata-rata $\mathrm{PH}$ air, suhu air dan kelembaban udara pada pengulangan I dan II tidak menunjukkan perbedaan yang signifikan. Kombinasi ekstrak daun mengkudu dan ekstrak daun papaya lebih efektif sebagai larvasida alami untuk kematian larva Aedes.
Saran

Disarankan penelitian selanjutnya ini melakukan analisis probit untuk mendapatkan nilai toksisitas (daya racun) suatu jenis insektisida terhadap serangga percobaan. Uji coba konsentrasi terbaik dengan waktu paling singkat untuk membunuh larva Aedes dari kombinasi ekstrak daun mengkudu dan daun papaya perlu dilakukan untuk penelitian selanjutnya. Pengujian terhadap insektisida kimiawi sebagai pembanding (control) terhadap insektisida alami perlu dilakukan untuk menyempurnakan penelitian ini.

\section{Daftar Pustaka}

1. WHO. Dengue: Guidlines for Diagnosis, Treatment, Prevention and Control. New Edition. Geneva: World Health Organization; 2014.

2. Kemenkes RI. Profil Kesehatan Indonesia Tahun 2017. Kementerian Kesehatan Republik Indonesia; 2018.

3. Dinkes Kota Tanjungpinang. Situasi DBD di Kota Tanjungpinang 2013-2017. Dinas Kesehatan Kota Tanjungpinang; 2018.

4. Dinkes Provinsi Kepri. Profil Kesehatan Provinsi Kepri 2017. Dinas Kesehatan Provinsi Kepulauan Riau; 2018.

5. Torres SM, et al. Cumulative Mortality of Aedes aegypti Larvae Treated with Compounds. Rev Saúde Pública. 48(3): 445-450; 2014.

6. Bamisaye FA, Ajani EO, dan Minari JB. Prospects of Ethnobotanical Uses of Pawpaw (Carica papaya) 1(4): 171-177; 2013.

7. Sopiyudin M. Statistik untuk Kedokteran dan Kesehatan, Jakarta, Epidemiologi Indonesia; 2010.

8. WHOPES. Managing pesticides in agriculture and public health -- An overview of FAO and WHO guidelines and other resources; 2009.

9. Notoatmodjo S. MetodologiPenelitian Kesehatan. Jakarta: Rineka Cipta; 2010.

10. Ariesta, Adhityas A, Suharyo dan Kriswiharsi KS. Uji Efektifitas Larutan Daun Pepaya ( Carica Papaya ) Sebagai Larvasida Terhadap Kematian Larva Nyamuk Aedes Aegypti Di Laboratorium B2p2vrp. Kesehatan Masyarakat Universitas Dian Nuswantoro; 2013.

11. Nisa K, et al. Uji Efektifitas Ekstrak Biji dan Daun Mengkudu (Morinda citrifolia L.) Sebagai Larvasida Aedes sp. Sel Vol. 2 No. 2 November 2015 : 43-48.

12. Amalia R. Daya Bunuh Air Perasan Daun Mengkudu (Morinda citrifolia) Terhadap Kematian Larva Aedes aegypt. Skripsi Universitas Negri Semarang, Semarang; 2016. 
13. Sang SM, et al. New Unusual Iridoids from The Leaves of Noni (Morinda citrifolia L.) Show Inhibitory Effect on Ultraviolet B-induced Transcriptional Activator Protein-1 (AP-1) Activity. Bioorg Med Chem, Vol. 11, No. 12; 2003.
14. La Sere dan Arismianti N. Pengaruh Ekstrak Daun Mengkudu (Morinda Citrifolia) Terhadap Kematian Larva Aedes sp. Skripsi Universitas Muhammadiyah Semarang; 2018. 